THE GLOBAL FACTOR IN NEUTRAL POLICY RATES:

SOME IMPLICATIONS FOR EXCHANGE RATES, MONETARY POLICY, AND POLICY COORDINATION

\author{
Richard H. Clarida \\ Working Paper 23562 \\ http://www.nber.org/papers/w23562 \\ NATIONAL BUREAU OF ECONOMIC RESEARCH \\ 1050 Massachusetts Avenue \\ Cambridge, MA 02138 \\ June 2017
}

This paper was prepared for the Annual BIS Research Conference held June 23rd, 2017 in Lucerne, Switzerland. The author would like to thank Jordi Gali for sharing his insights on this and related topics. The views expressed herein are those of the author and do not necessarily reflect the views of the National Bureau of Economic Research.

The author has disclosed a financial relationship of potential relevance for this research. Further information is available online at http://www.nber.org/papers/w23562.ack

NBER working papers are circulated for discussion and comment purposes. They have not been peer-reviewed or been subject to the review by the NBER Board of Directors that accompanies official NBER publications.

(C) 2017 by Richard H. Clarida. All rights reserved. Short sections of text, not to exceed two paragraphs, may be quoted without explicit permission provided that full credit, including ()$^{\circ}$ notice, is given to the source. 
The Global Factor in Neutral Policy Rates: Some Implications for Exchange Rates, Monetary

Policy, and Policy Coordination

Richard H. Clarida

NBER Working Paper No. 23562

June 2017

JEL No. E4,F31,F33

\begin{abstract}
This paper highlights some of the theoretical and practical implications for monetary policy and exchange rates that derive specifically from the presence of a global general equilibrium factor embedded in neutral real policy rates in open economies. Using a standard two country DSGE model, we derive a structural decomposition in which the nominal exchange rate is a function of the expected present value of future neutral real interest rate differentials plus a business cycle factor and a PPP factor. Country specific " $r$ "” shocks in general require optimal monetary policy to pass these through to the policy rate, but such shocks will also have exchange rate implications, with an expected decline in the path of the real neutral policy rate reflected in a depreciation of the nominal exchange rate. We document a novel empirical regularity between the equilibrium error in the VECM representation of the empirical Holston Laubach Williams (2017) four country $\mathrm{r}^{*}$ model and the value of the nominal trade weighted dollar. In fact, the correlation between the dollar and the 12 quarter lag of the HLW equilibrium error is estimated to be 0.7 . Global shocks to $\mathrm{r}^{*}$ under optimal policy require no exchange rate adjustment because passing though $\mathrm{r}^{*}$ shocks to policy rates 'does all the work' of maintaining global equilibrium. We also study a richer model with international spill overs so that in theory there can be gains to international policy cooperation. In this richer model we obtain a similar decomposition for the nominal exchange rate, but with the added feature that $\mathrm{r}^{*}$ in each country is a function global productivity and business cycle factors even if these factors are themselves independent across countries. We argue that in practice, there could well be significant costs to central bank communication and credibility under a regime formal policy cooperation, but that gains to policy coordination could be substantial given that $\mathrm{r}^{*}$ 's are unobserved but are correlated across countries.
\end{abstract}

Richard H. Clarida

Columbia University

420 West 118th Street

Room 1111, IAB

New York, NY 10027

and NBER

rhc2@columbia.edu 


\section{The Global Factor in Neutral Policy Rates: Some Implications for Exchange Rates, Monetary Policy, and Policy Coordination \\ Richard Clarida}

\section{Introduction}

Over the past 25 years, best practice monetary policy has been implemented with reference - if not with mechanical adherence - to interest rate feedback rules that Include as inputs estimates of both potential output as well as the real policy rate - often referred to the "neutral" real policy rate and denoted as $\mathrm{r}^{*}$ - consistent with potential output and price stability as defined by the central bank's inflation target. Before the global financial crisis and reflecting the justly deserved influence of Taylor (1993), it was common in policy simulations (Henderson and McKibbin (1993)) and in empirical work (Clarida, Gali, Gertler $(1998 ; 2000)$ ) to make the simplifying assumption that $\mathrm{r}^{*}$ is constant. However, it has long been appreciated (Wicksell (1898) ; Friedman (1968)) that $\mathrm{r}^{*}$ can be time varying and in particular, the theoretical analysis of monetary policy rules in Woodford (2003) and Clarida , Gali, Gertler $(1999 ; 2002)$ - among many others - has emphasized that shocks to $\mathrm{r}^{*}$ should be reflected in policy rates set by central banks seeking to keep the economy as close as possible to the benchmark of a flexible price equilibrium. Since the global financial crisis, estimated and projected future declines in neutral real policy rates (Laubach and Williams (2003); Holston, Laubach, Williams (2017)) ; Hamilton, et. al. (2015)) relative to the pre-crisis experience have become an important consideration in the conduct of monetary policy and the communication of forward guidance at the Fed and some other major central banks ( Yellen (2017); Haldane (2015)).

One obvious and significant implication of a persistent decline in the neutral real policy rate in any given country is that such a decline makes it more likely that a central bank will hit the effective perhaps somewhat less than zero - lower bound for any given inflation target and distribution of shocks . While these lower - bound and choice-of -inflation- target topics are important (and have recently been 
studied in the open economy context by Cook and Devereux (2013)), they are not the focus of this paper. Instead, the focus of this paper is on highlighting some of the theoretical and practical implications for monetary policy and foreign exchange rates that derive specifically from the presence of a global general equilibrium factor - predicted in theory and estimated in practice - embedded in neutral real policy rates in open economies. Empirically, as shown in a recent study by Ferrari, Kearns, and Schrimpf (2017) the exchange rate impact of monetary policy shocks has been growing significantly this appears to be related - and is certainly contemporaneous with - the observed decline in neutral policy rates (see also Gali (2017) for a model of forward guidance and exchange rates).

After reviewing in Section II some of the existing empirical evidence on the presence of a global factor in neutral policy rates, we present in Section III a simple two country model (based on GaliMonacelli (2005) and Clarida (2014)) to help illustrate several points about how shocks to neutral policy rates might impact monetary policy and exchange rates. We show that in this model, the neutral real policy rate in each country will be a function of expected productivity growth in that country, so that if there is a common factor across countries in productivity growth, there will be a common factor in neutral policy rates. If countries are adjusting policy in response to common, global neutral real rate shocks, this will obviously impart a positive correlation in policy even in the absence policy cooperation or coordination. In this particular model given the assumption on parameters, there is no gain to monetary policy cooperation; the Nash best response policy rules - which in this model take the form of Taylor type rules - lead to the maximum level of global welfare that can be obtained in the absence of a commitment device outside the model. As for exchange rates, we derive a decomposition for the (log) nominal exchange rate as the sum of a price level term, and business cycle term, and a term which is the present value of expected future neutral real policy rate differentials, with a decline in the expected future neutral policy rate below its long run level associated with a depreciation of the exchange rate today. In this model, exchange rate depreciation in the face of a country specific $\mathrm{r}^{*}$ shocks is not the outcome a 
'beggar thy neighbor' policy in either motive or realization, as trade is balanced period by period so that the exchange rate adjustment that occurs is required to maintain trade balance. Intuitively, if the country specific component of productivity is stationary, a positive shock to home productivity today sets up the expectation of future declines in productivity - and thus future declines in the neutral real interest rate in the future. The rise in productivity today requires the home real interest rate to fall to boost aggregate demand at home but is also requires the nominal exchange rate to depreciate to adjust the terms of trade so that foreign demand rises to absorb some of the rise in home supply. By contrast, in this model exchange rates do not need adjust to the global component in neutral policy rates, realized or expected. In response to a global shock, a common global decline in real policy rates can 'do all the work' to generate global aggregate demand in line with aggregate supply. This may look like, but is not in this model a globally inefficient 'currency war' defined as a 'race to the bottom' in policy rates as countries seek to avoid rate differentials and home currency appreciation as other countries cut interest rates.

In Section IV, we study a more general specification (based on CGG (2002)) of the two country model in which there are international spillovers that can lead, in theory, gains to international policy cooperation We argue however, that in practice, cooperation may be difficult to implement and communicate because in this model it would bind countries to set local policy rates based on an index of global inflation. Moreover, in this model with international spillovers, the neutral real policy rate in each country will depend on expected productivity growth in all countries (and potentially also global business cycle factors) even if there is no common factor in country productivity growth. As a result, there may be significant gains to policy coordination which are achievable in practice in the noncooperative equilibrium where again optimal policy can be written as a Taylor type rule.

Section V provides some concluding remarks. 


\section{A Quick Review of the Empirical Evidence}

As the motivation for this paper is the phenomenon of a time varying global factor in neutral real interest rates, it seems worthwhile at the outset to provide some evidence that these rates are time varying and that they appear correlated across countries. Similar to another input to monetary policy analysis - potential output - the neutral real policy rate is both time varying and unobservable and thus must be inferred from data. Laubach and Williams (2003) and more recently Holston, Laubach, and Williams (2017) have developed and implemented a widely cited methodology for estimating neutral real policy rates. The latter paper is especially useful for our purpose because it consistently applies the a common LW methodology to estimate neutral real policy rates in the US, UK, Canada, and Eurozone. Other papers - for example Hamilton, et al. (2015), King and Low (2014), Lucasz and Smith (2015), IMF (2013) - provide estimates that are also consistent with the presence of a global factor in time varying neutral real interest rates.

Figure 1: HLW Estimates of $r^{*}$

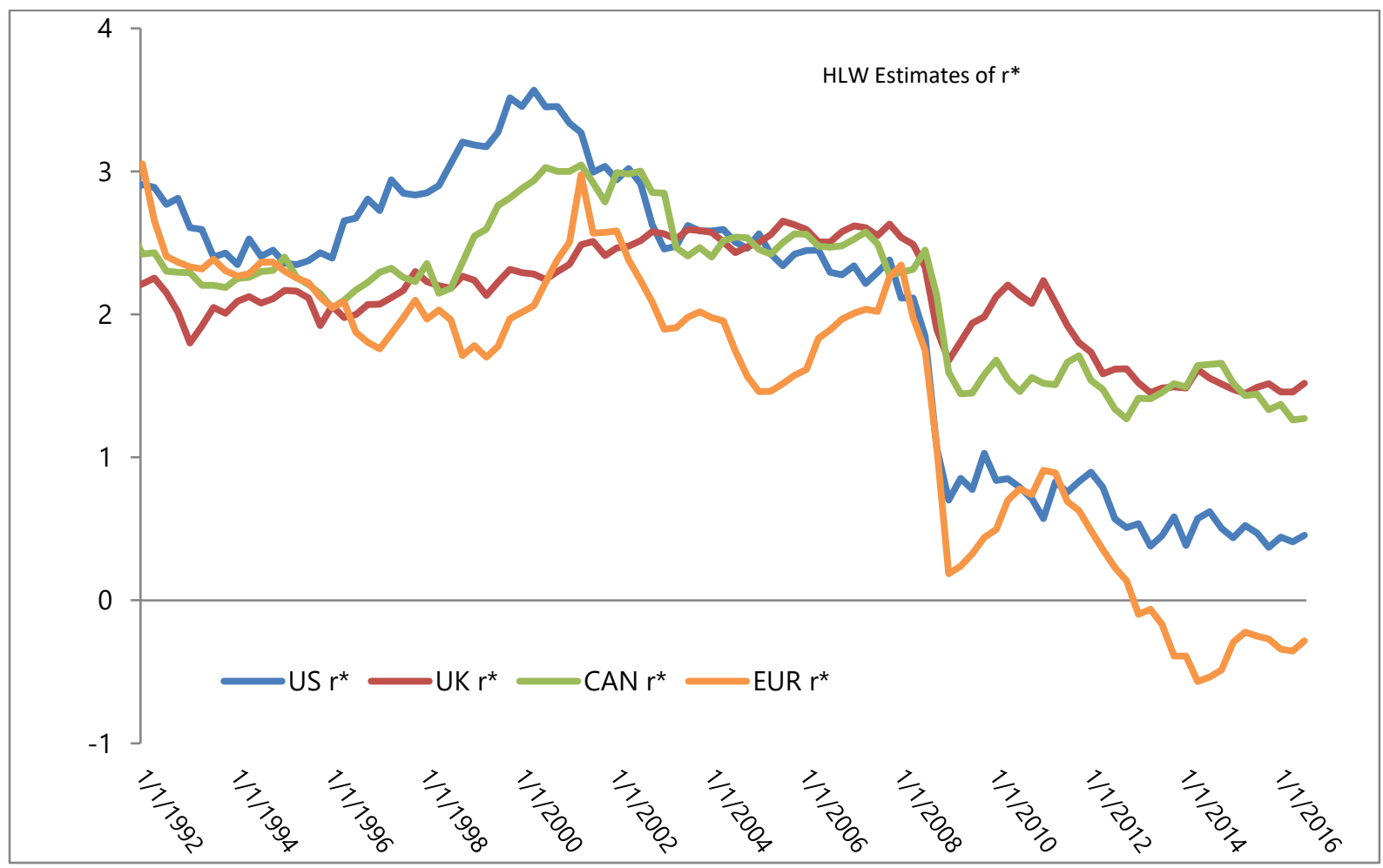


Figure 1 displays the HLW estimates of $r^{*}$ for the US, UK, Europe, and Canada as of July 2016.

For all four countries, estimates for recent years are well below those in the 1990s and in the years preceding the Global Financial Crisis. It is also interesting to note that for all countries, in the decade or so before the GFC, the estimates are clustered around $2 \%$ which of course is the assumed constant value for $\mathrm{r}^{*}$ in the original Taylor Rule. Figure 2, compares the HLW estimates of the US $\mathrm{r}^{*}$ with the 1 year TIPS yield 4 years forward as calculated by the Federal Reserve.

Figure 2: HLW $r^{*}$ and TIPS Implied Forward

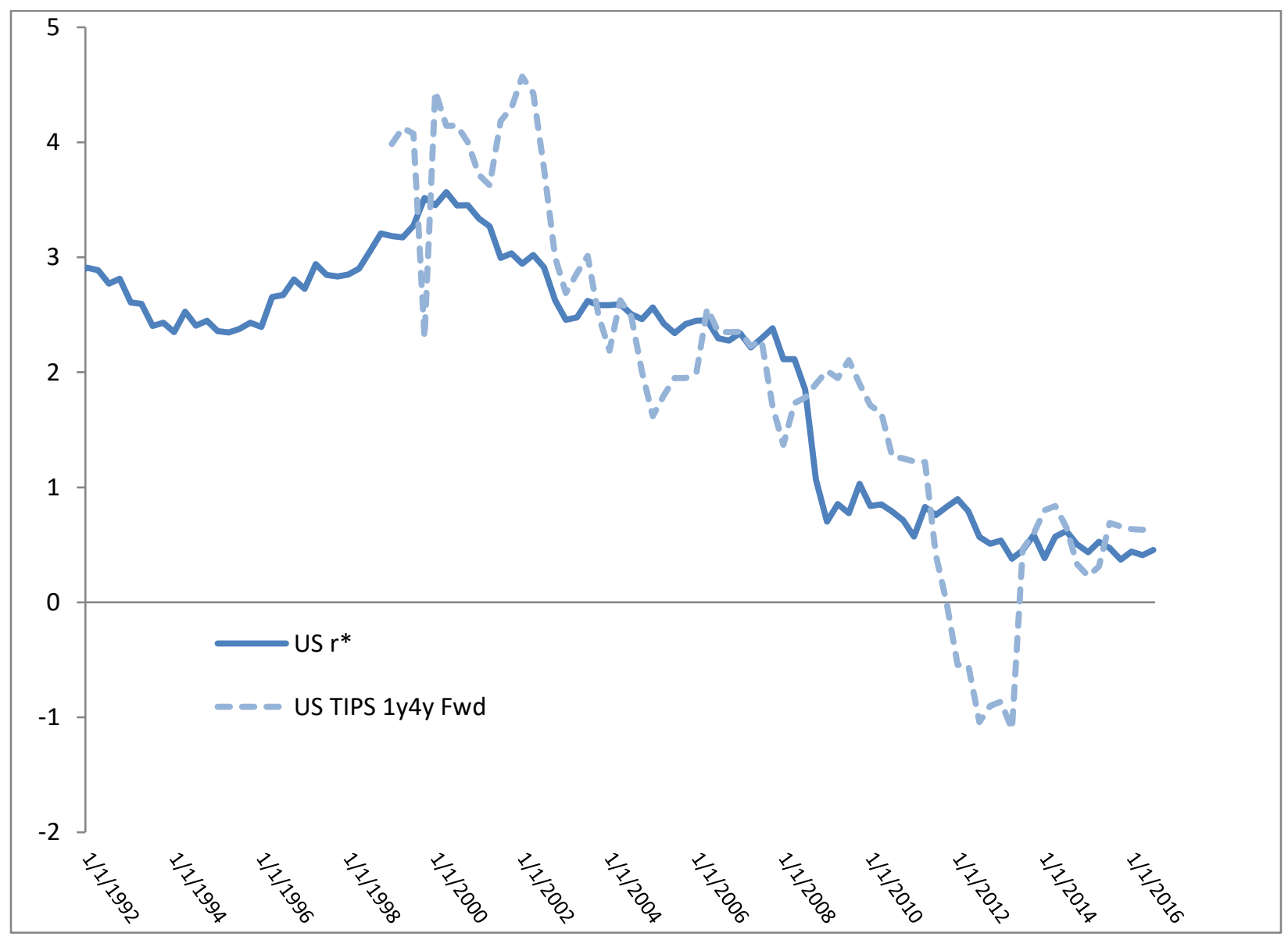

As the HLW econometric approach uses no data on TIPS yields or forwards so, the alignment between the two series is noteworthy. That said, as shown in Figure 3, there is a much looser relationship between forward real yields in the UK (as calculated by the Bank of England) and the HLW estimates of $\mathrm{r}^{*}$ for the UK. 
Figure 3: HLW r* and Implied Linker Forward

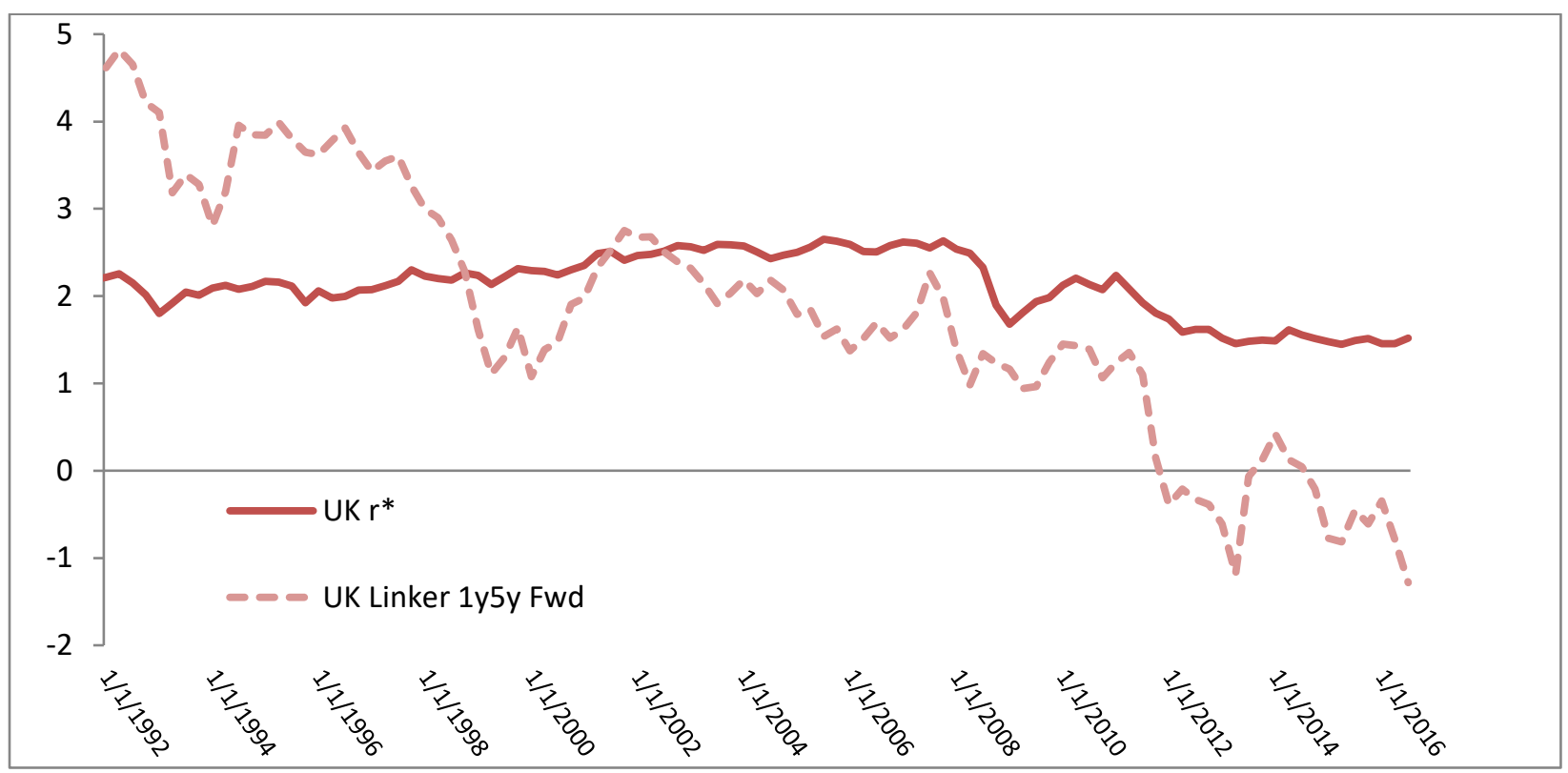

Finally, to get a sense of the co movement among the four neutral real policy rates, we plot the estimated $r^{*}$ for the US versus a weighted average of the $r^{*}$ estimates for the other three countries, with the weights equal to (minus) the estimated co integrating vector coefficients reported in HLW (2017) Table 3. The difference between these two series is the equilibrium error the VECM representation of the HLW system (since HLW normalize the US coefficient in the co-integrating vector to unity).

Figure 4:Equilbrium Error in the HLW VECM Representation

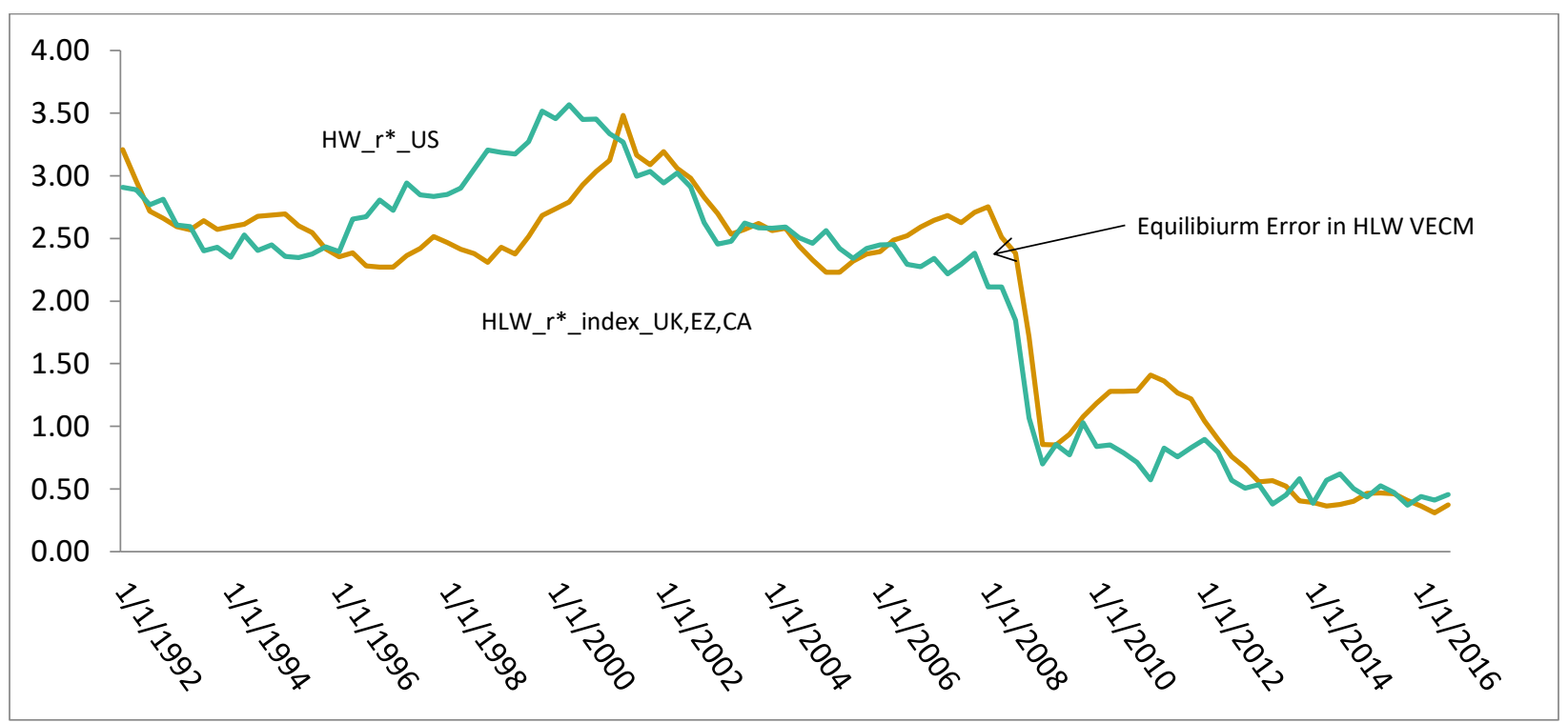




\section{A Simple Model of Optimal Monetary Policy and Exchange Rate Determination with $\mathbf{r}^{*}$ Shocks}

We begin with a tractable two country version of the Gail-Monacelli (2005) and Clarida (2014) DSGE model of optimal monetary policy and exchange rate determination extended to allow for global as well as country specific stocks to $r^{*}$. In this model, $r^{*}$ t shocks are driven by common as well as country specific shocks to home and foreign expected productivity growth. To focus on the main points, and without loss of generality, we assume in this section the 'foreign' country operates always at its supply determined level of output $Y^{F}{ }_{t}=A^{F}{ }_{t}=\bar{Y}_{t}{ }^{F}$ and that foreign monetary policy is such that the price of foreign output is constant and equal to 1 . By contrast, in the home country, 'cost push' shocks in the presence of nominal rigidities can cause output to deviate from its flexible price supply determined level of output so that $Y_{t}=A^{F_{t}} A_{t} X_{t}=\bar{Y}_{t} X_{t}$. In this model, aggregate home productivity is the product of a common global factor $\mathrm{A}^{\mathrm{F}}$ and a home-country specific factor $\mathrm{A}_{t}$. The home 'output gap', denoted $\mathrm{X}_{\mathrm{t}}$, is endogenous and will be solved for as a function of shocks and the monetary policy rule. An overstrike over a variable indicates its level in a flexible price equilibrium. In the model of this section, with our parameter choices, the flexible price level of output in each country is just equal to the exogenous level of productivity in that country.

Home utility takes the form $U\left(C_{t}\right)-V\left(N_{t}\right)=b \ln C_{H, t}+(1-b) \ln C_{F, t}-(1+\varphi)^{-1} N_{t}^{1+\varphi}$ where $C_{t}=$ $\left(C_{H, t}\right)^{b}\left(C_{F, t}\right)^{1-b}$ and $N_{t}$ is home labor supply and $b \geq 0.5$. These preference feature an intertemporal elasticity of substitution $1 / \sigma$ equal to 1 and a Cobb-Douglass aggregator for consumption. Households maximizes a discounted sum of expected utility subject to a sequence of budget constraints

$$
P_{t}^{c p i} C_{t}+\mathbf{E}_{t}\left\{M_{t, t+1} D_{t+1}\right\}=W_{t} N_{t}+D_{t}-T_{t}+\Gamma_{t}
$$

where $M_{\mathrm{t}, t+1}$ is a nominal stochastic discount factor, $\mathrm{W}_{\mathrm{t}}$ is the money wage, $\mathrm{D}_{\mathrm{t}}$ is the distribution paid on securities brought into date $t, T_{t}$ is lump sum tax collection, and $\Gamma_{t}$ is the distribution of profits earned by producers of intermediate inputs. Foreign preferences and budget constrains are symmetric. 
Up to log linearization, an Euler equation will characterize the equilibrium relationship between the log consumption index (relative to its level in a non-stochastic steady state), CPI inflation, and the one period nominal interest rate $R_{t}$

$$
c_{t}=\mathbf{E}_{t}\left\{c_{t+1}\right\}-\left(R_{t}-\mathbf{E}_{t} \pi^{c p i}{ }_{t+1}\right)
$$

With our assumptions on preferences, trade will be balanced period by period (Cole Obstfeld (1991)) and goods market equilibrium will imply $b A^{F_{t}} A_{t} X_{t}+(1-b) S_{t} A^{F_{t}}=A^{F_{t}} A_{t} X_{t}$ where $S_{t}$ is the equilibrium terms of trade (home good price of foreign good) and $b \geq 1 / 2$ is the expenditure share on locally produced output. This implies $S_{t}=A_{t} X_{t}$ or in $\log s S_{t}=a_{t}+x_{t}$ so that the log of the equilibrium terms of trade is equal to the home country specific factor in productivity at plus the log of the home 'output gap' $\mathrm{x}$. We assume the law of one price and producer currency pricing so that the log nominal exchange rate satisfies $\mathrm{e}_{\mathrm{t}}=\mathrm{St}_{\mathrm{t}}+\mathrm{p}_{\mathrm{t}}$ where $p_{t}$ is the log of the price of home output. We have $\pi^{c p i_{t+1}}=\pi_{t+1}+(1-b) \Delta s_{t+1}$ with $\pi_{t+1}=p_{t+1}-p_{t}$.

From balanced trade and goods market equilibrium $C_{t}=(b)^{b}(1-b)^{1-b} A^{F_{t}} A_{t} X_{t} S^{b-1} t$ Substituting out for $\mathrm{c} t$ and using the definition of CPI and the equilibrium condition for the terms of trade, we obtain an Euler equation in terms of the domestic output gap and the neutral real interest rate

$$
x_{t}=E_{t} x_{t+1}-\left\{R_{t}-E_{t}\left(p_{t+1}-p_{t}\right)-r_{t}^{*}\right\}
$$

where $r_{t}^{*}=E_{t} \Delta a^{F}{ }_{t+1}+E_{t} \Delta a_{t+1}$ is the ex-ante real interest rate in the home country that maintains the home output gap at zero. We have $r^{F^{*}}{ }_{t}=E_{t} \Delta a^{F} t+1$ period by period, $\pi^{\mathrm{F}_{t}}=0$ period by period, $R^{F_{t}} r^{F^{*}}{ }_{t}$ period by period, and $\mathrm{Y}_{\mathrm{t}}=\mathrm{A}^{\mathrm{F}} \mathrm{t}$ period by period. We assume that at is an auto correlated deviation of the log level of home productivity from the log level of global productivity $\mathrm{a}^{\mathrm{F}} \mathrm{t}$ which may itself possess a unit root. Note that under this stationarity assumption $a_{t}+E_{t} \sum_{i=1, \infty} \Delta a_{t+i}=0$ if the unconditional mean of at is 0 . 
Home firms will set prices as a markup over marginal cost - which is proportional to the real product wage scaled by productivity - in a staggered fashion a la Calvo. With our assumption on preferences, and letting $\delta=(1-F)(1-\beta F) / F$ with $(1-F)$ the fraction of firms that reset prices each period, inflation in the price of home goods will be given by

$$
p_{t}-p_{t-1}=\beta \mathbf{E}_{t}\left(p_{t+1}-p_{t}\right)+\lambda x_{t}+u_{t}
$$

where $\mathrm{u}_{\mathrm{t}}$ is a - possibly auto correlated - shock to the wage mark-up and $\lambda=(1+\varphi) \delta$.

The nominal exchange rate must be consistent with asset market equilibrium, goods market equilibrium, and long run purchasing power parity (which will hold in this model in expectation in the long run under our assumptions on productivity and preferences ). A structural equation which characterizes the equilibrium exchange rate in terms of endogenous variables can be written as

$$
e_{t}=p_{t}+x_{t}-\mathbf{E}_{t} \sum_{i=0}^{\infty}\left(r_{t+i}^{*}-r_{t+i}^{F^{*}}\right)
$$

where $r_{t}{ }^{*}-r^{F^{*}}{ }_{t}=\boldsymbol{E}_{t} \Delta a_{t+1}$ is the neutral real rate differential between the home country and the foreign country. Thus the log nominal exchange rate can be decomposed into the sum of a PPP component, $a$ business cycle component, and a (forward looking) $r^{*}$ component. Equivalently, persistent but transitory deviations from PPP are the sum of a business cycle component and an $r^{*}$ component. The nominal exchange rate today will reflect the entire expected future time path of the country specific component in the neutral real interest rate but in equilibrium does not adjust to the global component in the neutral policy rate. In particular, if today the neutral real rate at home is expected in the future to lie below the neutral real rate abroad, the nominal exchange rate today must weaken relative to domestic prices given the state of the business cycle $x_{t}$. Figure 5 depicts the empirical relationship between the nominal trade weighted dollar and the equilibrium error calculated using the parameters reported in HLW (2017) Table 3 and shown in Figure 4. The equilibrium error appears to lead the trade weighted dollar by about 12 quarters. The simple correlation between the TW Dollar and the VECM error lagged 12 quarters is 0.70 . 
Figure 5: US TWD vs. HLW Vecm Error

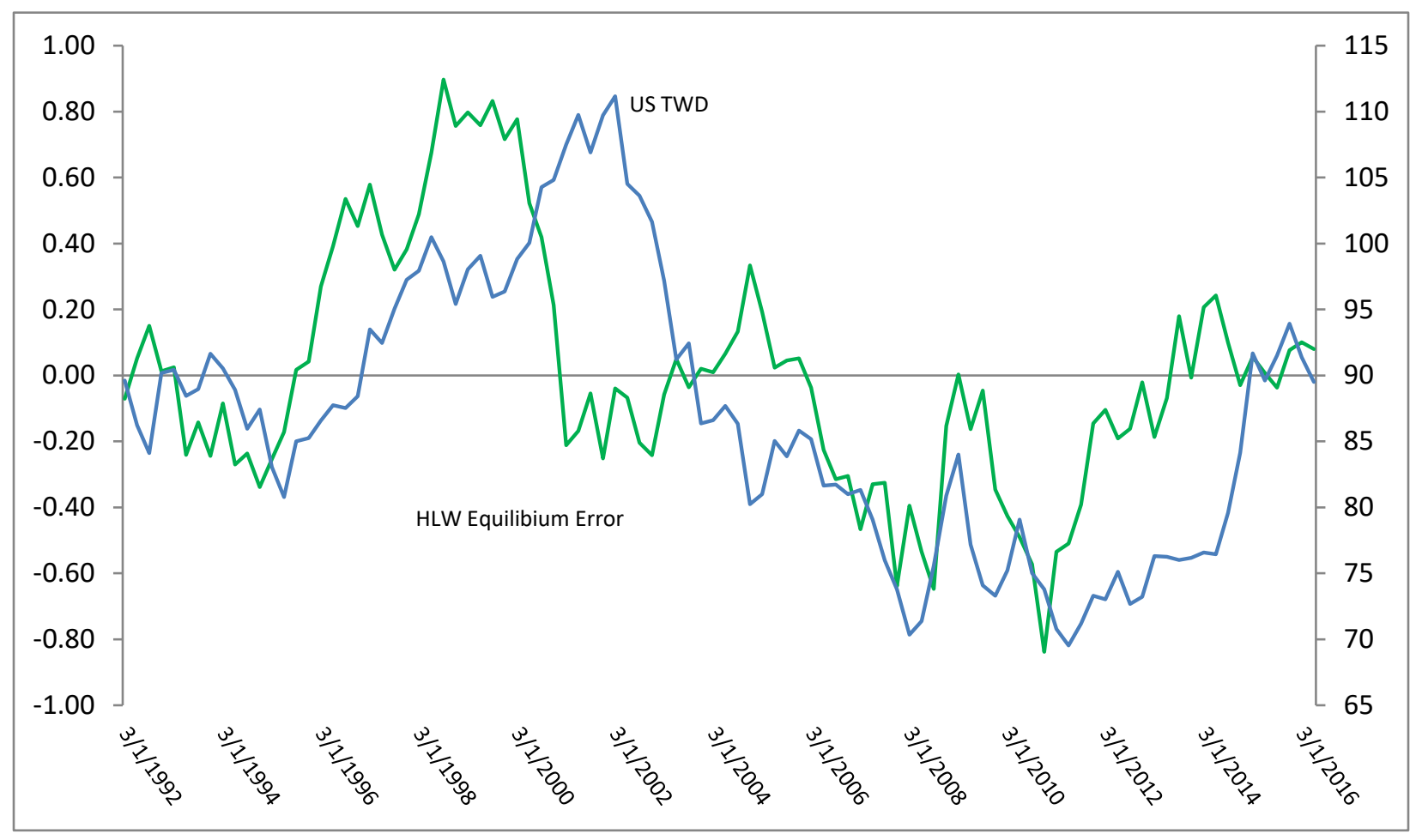

Figure 6: US TWD vs. HLW Vecm Error lead by 12 quarters

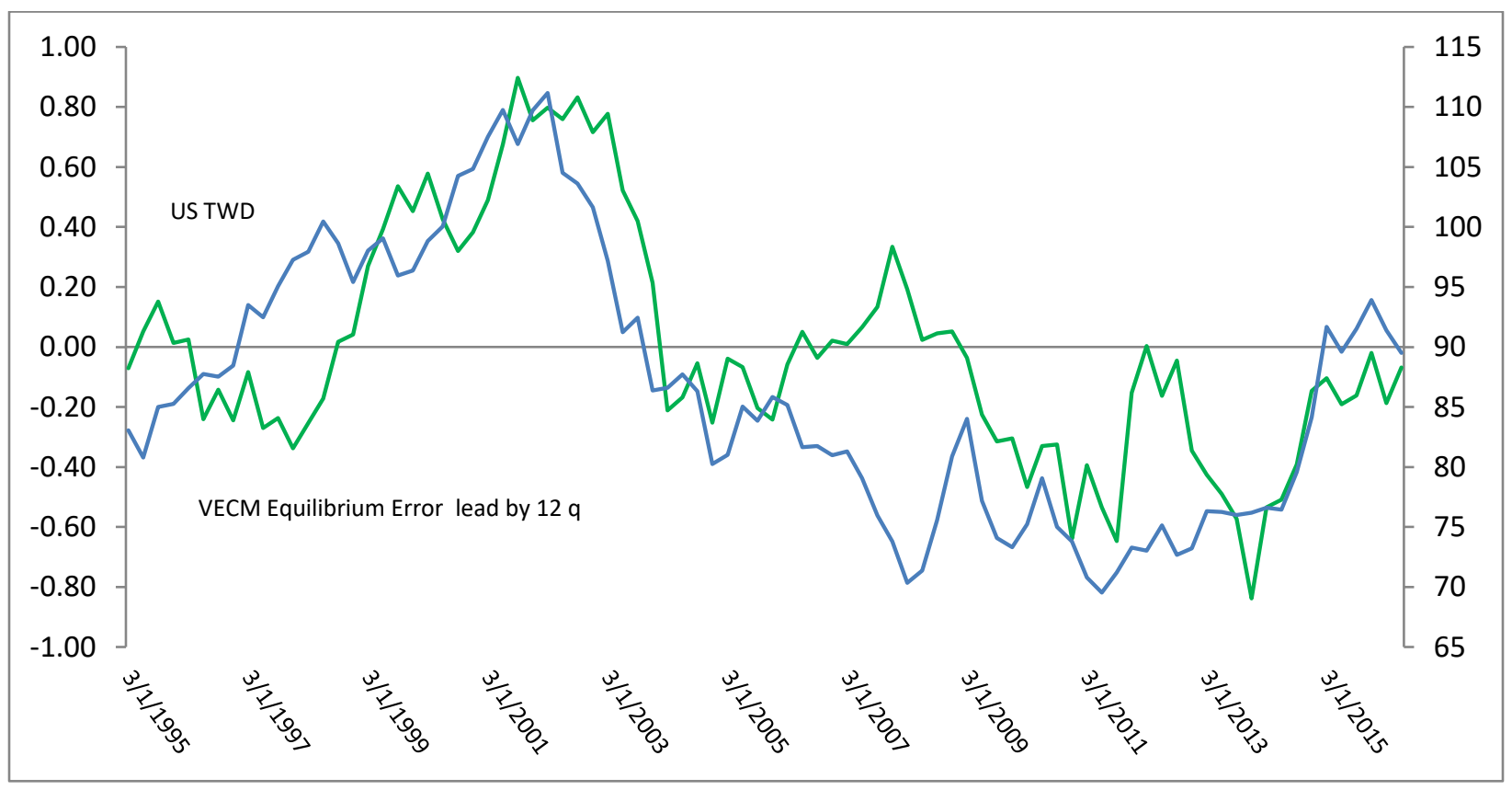


Notice that structural exchange rate equation (3) holds in any equilibrium regardless of how the rest of the model is closed. To close the model, we need to take a stand on monetary policy and the central bank objective function so we can pin down domestic inflation and the output gap. There are two ways to do this. We can just assume that the objective function is quadratic in inflation and the output gap with an arbitrary relative weight $\alpha$ on stabilizing home output at its natural level $a^{F}+a_{t}$. Or, as was derived in Clarida, Gali and Gertler (2002) and Gali Monacelli (2005), we can follow Woodford (2003) and solve for $\alpha$ - and thus the optimal policy rule - as a function of deep parameters. So for a policymaker who wants to maximize an objective function proportional to $W^{H}=-E_{0} \sum_{t=0}^{\infty} \beta^{t}\left[\pi_{t}^{2}+\alpha x_{t}^{2}\right]$ subject to the Philipps curve and the Euler and taking $E_{t} \pi_{t+1}$ as given, the first order condition will be $x_{t}=-\frac{\lambda}{\alpha} \pi_{t}$ which is of the same form as in Clarida, Gali and Gertler (1999). Since under optimal policy the output gap will be linear in domestic inflation, the equilibrium rate of inflation under optimal policy will satisfy $\pi_{t}=\beta E_{t}\left\{\pi_{t+1}\right\}-\left(\lambda^{2} / \alpha\right) \pi_{t}+u_{t}$. Solving forward and assuming $u_{t}=\rho u_{t-1}+\varepsilon_{t}$ we obtain

$$
\tau_{t}=\left(1-\beta \rho+\lambda^{2} / \alpha\right)^{-1} u_{t}
$$

or $\pi_{t}=\psi u_{t}$. The optimal policy rule given $\alpha$ is obtained by substituting the first order condition into the Euler equation and using equilibriums dynamics for inflation. The system can be written as follows:

$$
R_{t}=r_{t}^{*}+\left(1+\frac{\lambda(1-\rho)}{\alpha \rho}\right) \mathbf{E}_{t} \pi_{t+1}
$$

$$
\begin{gathered}
R_{t}^{F}=r_{t}^{F^{*}} \\
e_{t}=p_{t-1}+\left(\frac{\alpha-\lambda}{\alpha}\right) \psi u_{t}-\mathbf{E}_{t} \sum_{i=0}^{\infty}\left(r_{t+i}^{*}-r_{t+i}^{F^{*}}\right)
\end{gathered}
$$

with $r_{t}^{*}=E_{t} \Delta a^{F_{t}}+E_{t} \Delta a_{t}, r^{F_{t}^{*}}=E_{t} \Delta a_{t}^{F_{t}}$ and $E_{t} \pi_{t+1}=\rho \psi u_{t}$ and $p_{t-1}=\sum_{i=1, \infty} \psi u_{t-i}$. Thus optimal policy in the open economy can be written as a forward looking Taylor rule with a time varying neutral real interest rate . 
The time varying neutral real interest rate is, in turn, the sum of a global component and a country specific component. Also notice that above we focus on an equilibrium with inflation proportional to the exogenous cost push shock $u_{t}$. As is well known, there are other equilibria in this class of DSGE models which feature speculative hyperinflation, and this would be true even if we were to append a standard utility of real balances into the objective function (see for example Kocherlakota and Phelan (1999) for an insightful discussion of this issue).

Notice in this set up, under optimal monetary policy, there is a clean distinction between impact of neutral rate shocks (driven by forecastable changes in productivity growth) and cost push shocks. Under optimal policy neutral rate shocks should be reflected one for one in policy rates and will result in equilibrium adjustments in nominal exchange rate to the country specific component in neutral real rate shocks. These adjustments in policy rates and exchange rate are sufficient to keep the economy at its flexible price equilibrium even in the presence of nominal rigidities. Cost push shocks, by contrast, create a tradeoff between stabilizing output and inflation. Under optimal policy, the central bank follows a forward looking Taylor rule and raises the nominal interest rate by more than the rise in expected inflation. This optimal policy depresses output below the flexible price level so as to stabilize expected inflation. The optimal policy will also have implications for the nominal exchange which will be discussed below. Note that cost push shocks have no effect on the neutral policy rate unless those shocks are themselves correlated with productivity shocks.

These three equations illustrate several points about neutral real rate shocks in open economies under flexible exchange rates that are worth noting.

- The neutral real policy rate in the open economy will in general be a function of global as well local factors such as the rate of current and expected future potential growth. If countries are adjusting policy 
in response to common, global neutral real rate shocks, this will obviously impart a positive correlation in policy even in the absence policy coordination or cooperation.

-In this model with the parameter assumption we have made on the intertemporal elasticity of substitution, there is no gain to policy cooperation so that the Nash best response policy rules which here take the form of Taylor type rules - lead to the maximum level global welfare that can be obtained under discretion.

- The exchange rate is an asset price that will reflect, in part, expectations of the future time path of the country specific component of the neutral policy rate policy rate, with a decline in the expected future neutral policy rate below its long run level associated with a depreciation of the exchange rate today.

- However, exchange rate depreciation in the face of a persistent country specific $\mathrm{r}^{*}$ shock is not a 'beggar thy neighbor' policy in either motive or realization. In this simple model, trade is balanced period by period and so the exchange rate adjustment that occurs is required to maintain goods market equilibrium with balanced trade and not to generate a trade surplus.

- Exchange rate adjustment to a persistent country specific $r^{*}$ shock is required because expectations that future home neutral rates will remain below neutral rates in the rest of the world are coincident with expectations that home productivity and output are and will remain elevated relative to their long run levels, and this elevated supply requires a weaker nominal exchange rate and a worsening terms of trade as well as a lower neutral policy rate to generate the level and allocation of global aggregate demand to clear the home and world goods market. In symbols $-\mathrm{E}_{\mathrm{t}} \sum_{\mathrm{i}=1, \infty} \mathrm{r}^{*}{ }_{\mathrm{t}}=\mathrm{at}$

- By contrast, at least under optimal policy, exchange rates do not need to adjust to the global component in neutral policy rates, realized or expected. In response to a global shock, a common global decline in real policy rates can 'do all the work' to generate global aggregate demand in line with aggregate supply; 
- This may look like, but is not a globally inefficient 'currency war' defined as a 'race to the bottom' in policy rates as countries seek to avoid home currency appreciation as other countries cut interest rates.

An interesting feature of these models which finds a great deal of empirical support and is discussed extensively in CGG (2002); Clarida Waldman (2007); Krugman Obstfeld Melitz (9 ${ }^{\text {th }}$ edition) ; and Clarida (2014) is the 'bad news good news' result that, with an inflation targeting central bank, a shock that pushes inflation above target can trigger the expectation of a policy rate path that results in an appreciation of the nominal exchange rate today even though in the long run the exchange rate must (in expectation) depreciate to return to PPP. In our model, bad news for inflation resulting from a positive cost push shock to ut will appreciate the nominal exchange rate today if $\alpha$ - the welfare weight on output stabilization - is less than $\lambda$ - the slope of the Philipps curve.

$$
e_{t}=p_{t-1}+\left(\frac{\alpha-\lambda}{\alpha}\right) \psi u_{t}-\mathbf{E}_{t} \sum_{i=0}^{\infty}\left(r_{t+i}^{*}-r_{t+i}^{F^{*}}\right)
$$

A 'cost push' shock ut will increase domestic inflation and under optimal policy induce the central bank to raise the nominal interest rate by more than expected inflation. The rise in the ex-ante real interest rate will cause st to fall and this, along with the rise in the real interest rate itself, will reduce demand for home output. In the 'bad news good news' case the equilibrium decline in st is larger in absolute value than is the equilibrium rise in inflation, and this can only be accomplished via an appreciation of the nominal exchange rate More broadly, the equilibrium nominal exchange rate in this model must possess a unit root even though shocks are stationary and our Cole-Obstfeld equilibrium replicates the complete market allocation. The nominal exchange rate must possess a unit root because time consistent monetary policy cannot deliver a stationary price level, only a stationary rate of inflation (Clarida, Gali and Gertler (2002); Woodford (2003)). The unit root in the nominal exchange rate is required to produce a stationary equilibrium terms of trade given that optimal monetary policy produces unit root in the price level. 


\section{Policy Correlation, Gains from Policy Coordination, but Potential Pitfalls from Policy Cooperation}

Although these are absent in the simple model of Section III, in general there may be international spillovers to monetary policy that are not fully incorporated in Taylor - type rules that feedback solely on domestic macroeconomic variables. If so, there can in theory be gains to monetary policy cooperation. However, while we observe that national monetary policies are often correlated (eras of global monetary easing; global rate hike cycles), they also appear sometimes to be coordinated (after all, what else are central bankers doing at all those G7 , G20, IMF, and Basel meetings?) , but rarely (if ever) do major central banks respect a binding commitment to pursue cooperative policies, policies that would differ from non-cooperative policies aimed solely at satisfying their objectives for domestic inflation and employment. It has long been well appreciated (Taylor (1982)) that in small or large scale open economy macro models, the calibrated gains to international monetary policy cooperation (see for example, Obstfeld and Rogoff (2002)) are found to be modest relative to the welfare achieved under a Nash equilibrium in which each country runs a sensible policy taking as given the policy of the other countries. In this section, we will make a somewhat different and less often discussed case against global monetary policy cooperation even in a world of $r^{*}$ shocks. Namely, that in practice, adopting it - or succumbing to it! - could plausibly erode central bank credibility and public support for sound, rules based policies. According to this view, the all - in cost to a regime of policy cooperation could swamp the theoretical benefits, and if so, we should not bemoan the absence of formal monetary policy cooperation, we should celebrate it!

However, and perhaps especially in a world in which there is a common global component in neutral real policy rates across countries, international monetary policy coordination - defined to include the sharing of information and analysis regarding estimates of the unobservable inputs to policy rules such as the equilibrium real rate of interest and potential output as well as the considerations that would govern the timing and trajectory of a baseline policy path as well as trigger deviations from such a path - 
can enhance the design and effectiveness of baseline policy rules. We will give examples below. But while international monetary policy coordination may enhance the efficiency of a policy rule framework if it is in place, there are reasons to doubt that in practice there are likely to additional material, reliable, and robust gains that would flow from a formal regime of binding monetary policy cooperation, at least among major G7 economies and even including a number of emerging economies with flexible exchange rates and relatively open capital accounts. In such a regime, national monetary policies in each country are constrained to be set so as to jointly maximize world welfare. In these models, as in the earlier literature they build on, there are externalities to monetary policy that create such theoretical gains to cooperation. However, as Clarida, Gali, and Gertler (2002) and Engel (2009) illustrate in 'new Keynesian' models, and as we review below, to achieve the theoretical gains to international monetary policy cooperation, policy rates in each country must be set with reference to an index of inflation deviations from target in both the home and the foreign countries. In words, whereas optimal policy in the absence of cooperation can be implemented with a policy rule that reacts to domestic inflation, output gaps, and the appropriately defined equilibrium - or neutral - real interest rate, a global welfare increasing policy must bind central banks to policy rules that react to foreign as well as domestic inflation, policy rules that they would not chose were they not bound.

In practice, there could be another problem with policy cooperation in that is absent from most theoretical discussions. Simply stated, the problem is the threat to the credibility of the central bank , the challenges to central bank communication, and the resulting potential loss of support for its policy actions from the public when the policy choices required by cooperation react not only to home inflation but also to deviations of foreign inflation from target. For example, if home inflation is above target but foreign inflation is below target, the optimal policy rule under cooperation calls for the home (real) policy rate to be lower - more accommodative - than it would be in the absence of cooperation (Clarida, Gali, Gertler (2002)) . In theoretical models, the commitment to the inflation target is just assumed to be 
perfect and credible, but in practice credibility appears to be a function of central bank communication and as well the policies actually implemented to push inflation toward - and in the absence of shocks, to keep inflation at- target. In practice, central banks could have a hard time maintaining credibility as well as communicating a policy that kept home real interest rates low - or in extreme cases negative - not because home inflation is too low, but because foreign inflation is too low! Or imagine the opposite case, with home inflation below target when foreign inflation is above target. In this case, the optimal policy rule under cooperation calls for the home (real) policy rate to be higher - less accommodative - than it would be in the absence of cooperation, not because home inflation is too high, but because foreign inflation is!

While, perhaps for these reasons, we do not have many confirmed sightings of genuine monetary policy cooperation, we do perhaps observe rather more examples of as policy coordination. The CGG (2002) model - which is a generalization of the model of Section III - provides an illustration of the value of policy coordination in the non-cooperative Nash equilibrium in a symmetric two country model. We now allow for $\sigma>1$ but set $b=1 / 2$ so as to focus on the tractable symmetric case. Under these conditions the Cole Obstfeld result will still hold and trade will be balanced period by period. The log nominal exchange rate consistent with goods market equilibrium will satisfy

$$
e_{t}=p_{t}-p^{F}{ }_{t}+\bar{y}_{t}-\bar{y}_{t}^{F}+x_{t}-x_{t}^{F}
$$

The neutral real interest rate that clears the home goods market at the flexible price level of output conditional on foreign output is given by (see CGG(2002); Clarida (2014) for all derivations)

$$
r_{t}^{*}=\frac{(\sigma+1)}{2} E_{t} \Delta \bar{y}_{t+1}+\frac{(\sigma-1)}{2} E_{t} \Delta \bar{y}_{t+1}^{F}+\frac{(\sigma-1)}{2} E_{t} \Delta x_{t+1}^{F}
$$

The neutral real interest rate that clears the foreign goods market at the flexible price level of output conditional on home output is given by

$$
r_{t}^{F^{*}}=\frac{(\sigma+1)}{2} E_{t} \Delta \bar{y}_{t+1}^{F}+\frac{(\sigma-1)}{2} E_{t} \Delta \bar{y}_{t+1}+\frac{(\sigma-1)}{2} E_{t} \Delta x_{t+1}
$$


The neutral real rate differential is given by

$$
r_{t}^{*}-r_{t}^{F^{*}}=E_{t}\left(\Delta \bar{y}_{t+1}-\Delta \bar{y}_{t+1}^{F}\right)+\frac{(\sigma-1)}{2} E_{t}\left(\Delta x_{t+1}^{F}-\Delta x_{t+1}\right)
$$

Note that in the special case $\sigma=1$ these equations simplify to their counterparts in Section III. Under our assumptions that $\mathrm{at}_{\mathrm{t}}, \mathrm{u}_{\mathrm{t}}$, and $\mathrm{ut}^{\mathrm{F}}$ are stationary with zero mean, the unconditional mean of home output is equal to the mean of foreign output and the unconditional means of the output gaps are zero. It follows that

$$
e_{t}=p_{t}-p_{t}^{F}+\frac{(\sigma+1)}{2}\left(x_{t}-x_{t}^{F}\right)-\mathbf{E}_{t} \sum_{i=0}^{\infty}\left(r_{t+i}^{*}-r_{t+i}^{F^{*}}\right)
$$

As in the simpler model of Section III, we have a structural equation that decomposes the nominal exchange rate into a PPP term, a (relative) business cycle term, and a (forward looking) neutral real rate term. Ceteris paribus, it is again the country specific component of the home neutral real rate that is reflected in equilibrium nominal exchange rate, with a decline in the neutral rate inducing a depreciation of the nominal exchange rate.

In the simple model of Section III, the neutral real rate in each country is solely a function of that country's expected rate of productivity growth. However, when there are cross country spillovers, this will not be the case and instead, the neutral real rate in each country will be in equilibrium be a function home and foreign productivity growth as well as the home and foreign business cycle factors $x_{t}$ and $x_{t} F_{t}$. To see this, begin with the equations for flexible price output at home abroad derived in CGG (2002):

$$
\bar{y}_{t}=\left(\frac{\sigma+1}{2}+\phi\right)^{-1}\left[(1+\phi)\left(a_{t}+a_{t}^{F}\right)+\frac{(1-\sigma)}{2} \bar{y}_{t}^{F}+\frac{(1-\sigma)}{2} x_{t}^{F}\right]
$$

$$
\bar{y}_{t}^{F}=\left(\frac{\sigma+1}{2}+\phi\right)^{-1}\left[(1+\phi) a^{F}{ }_{t}+\frac{(1-\sigma)}{2} \bar{y}_{t}+\frac{(1-\sigma)}{2} x_{t}\right]
$$


These two linear equations can be solved for $\bar{y}_{t}$ and $\bar{y}_{t}^{F}$ each as a function of $a_{t}, a_{t}^{F}, x_{t}, x_{t}^{F_{t}}$. It follows that

$$
r_{t}^{*}=\frac{(\sigma+1)}{2} E_{t} \Delta \bar{y}_{t+1}\left(\Delta a_{t+1}, \Delta a_{t+1}^{F}, \Delta x_{t+1}, \Delta x_{t+1}^{F}\right)+\frac{(\sigma-1)}{2} E_{t} \Delta y_{t+1}^{F}\left(\Delta a_{t+1}, \Delta a_{t+1}^{F}, \Delta x_{t+1}, \Delta x_{t+1}^{F}\right)
$$

$$
r_{t}^{F^{*}}=\frac{(\sigma+1)}{2} E_{t} \Delta \bar{y}_{t+1}^{F}\left(\Delta a_{t+1}, \Delta a_{t+1}^{F}, \Delta x_{t+1}, \Delta x_{t+1}^{F}\right)+\frac{(\sigma-1)}{2} E_{t} \Delta y_{t+1}\left(\Delta a_{t+1}, \Delta a_{t+1}^{F}, \Delta x_{t+1}, \Delta x_{t+1}^{F}\right)
$$

which reduce to $r_{t}^{*}=E_{t} \Delta a_{t}^{F_{t}}+E_{t} \Delta a_{t}$ and $r^{F^{*}}{ }_{t}=E_{t} \Delta a_{t}^{F_{t}}$ in the $\sigma=1$ case. Letting $\Psi_{t}=\bar{y}_{t}-\bar{y}_{t}^{F}$ denote the flexible price output differential we have $\Psi\left(a_{t}, x_{t}, x_{t}^{F}\right)$ so that the flexible price output differential is in equilibrium a function of relative home productivity - as in the simpler model of Section III - as well as the home and foreign output gaps. In sum, regardless of how we close the model we must have

$$
e_{t}=p_{t}-p_{t}^{F}+\frac{(\sigma+1)}{2}\left(x_{t}-x_{t}^{F}\right)-\mathbf{E}_{t} \sum_{i=0}^{\infty}\left(r_{t+i}^{*}-r_{t+i}^{F^{*}}\right)
$$

with

$$
r_{t}^{*}-r_{t}^{F^{*}}=E_{t} \Psi\left(\Delta a_{t+1}, \Delta x_{t+1}, \Delta x_{t+1}^{F}\right)+\frac{(\sigma-1)}{2} E_{t}\left(\Delta x_{t+1}^{F}-\Delta x_{t+1}\right)
$$

We close the model with an policy rule that is the optimal best response taking the other country's output as given. In the 'home' country CGG (2002) show that the optimal Nash monetary policy rule can be written as a forward looking Taylor rule

$$
R_{t}=r_{t}^{*}+\left(1+\frac{\lambda(1-\rho)}{\alpha \rho} \frac{\sigma+1}{2}\right) E_{t} \pi_{t+1}
$$

And similarly in the foreign country

$$
R_{t}=r^{F^{*}}+\left(1+\frac{\lambda(1-\rho)}{\alpha \rho} \frac{\sigma+1}{2}\right) E_{t} \pi^{F}{ }_{t+1}
$$

Under the optimal Nash monetary policies we still have

$$
x_{t}=-\frac{\lambda}{\alpha} \pi_{t} \quad \text { and } \quad x^{F}{ }_{t}=-\frac{\lambda}{\alpha} \pi^{F}
$$

And so under optimal policy as before $\pi_{t}=\left(1-\beta \rho+\lambda^{2} / \alpha\right)^{-1} \mathcal{u}$ and $\pi^{F}{ }_{t}=\left(1-\beta \rho+\lambda^{2} / \alpha\right)^{-1} \mathcal{u}^{F}$. 
In this more general model, the neutral real interest rate in each country will be a linear function of home and foreign productivity as well as the cost push shocks, and this will be true even if home and foreign productivity are independent (see equation block (12)). Thus, even if there is no global component to productivity there will be in general equilibrium be a global component to the neutral real interest rate because of the cross country spillovers that arise when $\sigma$ is not equal to 1 . We illustrate this with a numerical example. Let $\sigma=3$ and $\varphi=1$ and solve equation block (11) for home and foreign flexible price output for the case in which home productivity is independent of foreign productivity (so that log productivity at home is equal to at instead of $\mathrm{at}_{\mathrm{t}}+\mathrm{a}_{\mathrm{t}}$ in equation block (11)). The solutions are

$$
\bar{y}_{t}=\frac{6}{8} a_{t}+\frac{1}{8} x_{t}-\frac{2}{8} a_{t}^{F}-\frac{3}{8} x_{t}^{F} \quad \text { and } \quad \bar{y}_{t}{ }_{t}=\frac{6}{8} a^{F_{t}}+\frac{1}{8} x^{F}{ }_{t}-\frac{2}{8} a_{t}-\frac{3}{8} x_{t}
$$

which imply that relative flexible price output is simply

$$
\bar{y}_{t}-\bar{y}_{t}^{F}=a_{t}-a_{t}^{F}+\frac{1}{2}\left(x_{t}-x_{t}^{f}\right)
$$

So from equation (12) we have for these parameters

$$
r_{t}^{*}=2 \mathbf{E}_{t}\left(\frac{6}{8} \Delta a_{t+1}+\frac{1}{8} \Delta x_{t+1}-\frac{2}{8} \Delta a_{t+1}^{F}-\frac{3}{8} \Delta x_{t+1}^{F}\right)+\mathbf{E}_{t}\left(\frac{6}{8} \Delta a^{F}{ }_{t+1}+\frac{9}{8} \Delta x_{t+1}^{F}-\frac{2}{8} \Delta a_{t+1}-\frac{3}{8} \Delta x_{t+1}\right)
$$

which simplifies to

$$
r_{t}^{*}=\frac{10}{8} \Delta a_{t+1}+\frac{2}{8} \Delta a_{t+1}^{F}+\frac{3}{8} \Delta x_{t+1}^{F}-\frac{1}{8} \Delta x_{t+1}
$$

and symmetrically for the foreign country. So in general, even if home and foreign productivity are uncorrelated, the neutral real rate in each country will be a function of both home and foreign productivity.

The best Nash policy in this two country model is a Taylor type rule for setting the policy rate as a function of expected home inflation and time varying equilibrium home real interest rate which is function of expected home and foreign productivity growth as well as the expected change in home and foreign output gaps. Thus, to the extent the foreign central bank has some comparative advantage in 
nowcasting (in the rigorous sense of Giannone, Reichlin, and Small (2008)) or forecasting foreign

productivity growth and business cycle factors, sharing this information or even pooling these nowcasts with the home central bank could improve its estimate of the home equilibrium real interest rate and thus the effectiveness of its policy rule in meeting its domestic objectives. While in the simple models of Section III and IV the global drivers of the $\mathrm{r}^{* \prime}$ s are assumed to be observed and with known values of the parameters mapping them to neutral policy rates, in practice this is not the case and coordination in such signal extraction efforts could be very valuable.

As discussed above, to achieve the theoretical gains from monetary policy cooperation in these models it no longer suffices for the policymaker to follow an instrument rule based solely on domestic inflation and the neutral real interest rate. Instead, under cooperation the home central bank must set the policy rate as a function of home and foreign variables. In its simplest form, this rule can be written as

$$
R_{t}=r^{*}+\left(1+\frac{\lambda(1-\rho)}{\alpha \rho} \frac{\sigma+1}{2}\right) E_{t} \pi_{t+1}+\frac{\sigma-1}{\sigma+1+2 \varphi}\left(\frac{\lambda(1-\rho)}{\alpha \rho} \frac{\sigma+1}{2}\right) E_{t} \pi^{F}{ }_{t+1}
$$

In sum, not only do the quantitative gains from time inconsistent cooperative monetary policy rules appear to be modest, but in addition the policy rules required to implement the cooperative outcome could well be difficult to communicate and to adhere to without sacrificing the credibility of the inflation target and the policy regime itself. 


\section{Concluding Remarks}

We have reviewed some simple examples based on rigorous models which can i) generate monetary policy correlation - via the global factor present in each country's equilibrium real interest rate; ii) rationalize the alleged benefits to monetary policy coordination ; but iii) provide some intuition for why binding monetary policy cooperation is rare in practice if not in academic papers. We have focused on the global factor in neutral real policy rates and shown how a plausible source of fluctuations in these rates (productivity growth with a global as well as country specific component) also can trigger adjustment in the nominal exchange rates. A country specific shock that pushes the expected path of the home $r^{*}$ below the foreign $r^{*}$ requires a depreciation of the home nominal exchange rate to maintain global equilibrium even with balanced trade. By contrast, a common global shock that depresses home and foreign neutral real policy rates equally will have no exchange rate implications. While these models are quite simple and in particular omit important potential additional drivers of neutral real policy rates - such as asset market imperfections and institutional and individual desires to hold safe assets - they are rich enough to shed light on the importance of global general equilibrium considerations in accounting for and inferring shifts in country neutral policy rates. One topic for future research is modeling medium and long horizon forecastable changes in neutral real policy rates as are estimated by HLW. The neutral real rates that we solve for in the models of Sections III and IV are the rates consistent with the stochastic flexible prices equilibrium in these workhorse DSGE models and may be thought of a 'short run' $\mathrm{r}^{* \prime} \mathrm{s}$. In the models of Section III and IV, the unconditional mean of these home and foreign $\mathrm{r}^{* \prime} \mathrm{s}$ are constant and equal. A worthwhile extension beyond the scope of this paper would be to introduce non stationary dynamics and or segmented trends (Rappoport and Rechlin (1989)) into relative productivity levels which would allow for a tighter linkage between the HLW econometric methodology and the theoretical modeling of time variation in $\mathrm{r}^{*}$. 


\section{References}

Calvo, G., "Staggered Prices in a Utility-Maximizing Framework," Journal of Monetary Economics 12: 383398 (1983).

Clarida, Richard H. "Monetary policy in open economies: Practical perspectives for pragmatic central bankers." Journal of Economic Dynamics and Control 49 (2014): 21-30.

Clarida, R., J Gali, and Gertler, “ Monetary Policy Rules in Practice: Some International Evidence,” European Economic Review, (1998). “The Science of Monetary Policy," Journal of Economic Perspectives, (1999). "A Simple Framework for International Monetary Policy Analysis," Journal of Monetary Economics 49: 879-904 (2002).

Clarida, R and D Waldman, "Is Bad News about Inflation Good News for the Exchange Rate" in John Campbell, Editor, Asset Prices and Monetary Policy, Chicago: University of Chicago Press, 2008.

Cole, H L., and M Obstfeld, "Commodity Trade and International Risk Sharing: How Much Do Financial Markets Matter?" Journal of Monetary Economics 28: 3-24 (1991).

Cook, David, and Michael B. Devereux. "Sharing the burden: monetary and fiscal responses to a world liquidity trap." American economic Journal: macroeconomics 5, no. 3 (2013): 190-228.

Engel, C. Currency misalignments and optimal monetary policy: a reexamination. No. w14829. National Bureau of Economic Research, 2009.

Ferrari, Massimo, Jonathan Kearns, and Andreas Schrimpf. "Monetary shocks at high-frequency and their changing FX transmission around the globe." (2016).

Friedman, M. "The Role of Monetary Policy" The American Economic Review 58, no. 1 (1968).

Galí, J. Monetary Policy, inflation, and the Business Cycle: An introduction to the new Keynesian Framework. Princeton University Press, 2008.

“Forward Guidance and Exchange Rates", mimeo, CREI, May 2017.

Gali, J, and T Monacelli, "Monetary Policy and Exchange Rate Volatility in a Small Open Economy," Review of Economic Studies 72: 707-734 (2005)

Giannone, D., Reichlin, L. and Small, D., 2008. Nowcasting: The real-time informational content of macroeconomic data. Journal of Monetary Economics, 55(4), pp.665-676. 
Haldane, Andrew G. "Stuck" speech by Chief Economist." Bank of England, Open University, Milton Keynes 30 (2015).

Hamilton, James D., Ethan S. Harris, Jan Hatzius, and Kenneth D. West. "The equilibrium real funds rate: Past, present, and future." IMF Economic Review 64, no. 4 (2016): 660-707.

Henderson, D. W., \& McKibbin, W. J.,"A Comparison of some basic monetary policy regimes for open economies: implications of different degrees of instrument adjustment and wage persistence." In Carnegie-Rochester Conference Series on Public Policy (1993, Vol. 39, pp. 221-317). North-Holland.

Holston, Kathryn, Thomas Laubach, and John C. Williams. "Measuring the natural rate of interest: International trends and determinants." Journal of International Economics (2017).

IMF World Economic Outlook , Fall (2013).

King, Mervyn, and David Low. Measuring the"world"real interest rate. No. w19887. National Bureau of Economic Research, 2014.

Kocherlakota, Narayana, and Christopher Phelan. "Explaining the fiscal theory of the price level." Federal Reserve Bank of Minneapolis. Quarterly Review-Federal Reserve Bank of Minneapolis 23, no. 4 (1999): 14.

Krugman, P. M. Obstfeld, M. Melitz, International Economics Prentice Hall Page 2011

Kydland, F E., and E C. Prescott. "Rules rather than discretion: The inconsistency of optimal plans." The Journal of Political Economy (1977): 473-491.

Laubach, T, and J. C. Williams. "Measuring the natural rate of interest." Review of Economics and Statistics 85.4 (2003): 1063-1070.

Lukasz, R. and T. Smith, "Secular Drivers of Global real Interest Rates," bank of England discussion paper 571 (2015).

Obstfeld, M. and K. Rogoff, Foundations of International Macroeconomics, MIT Press, 1997.

economics 50.1 (2000): 117-153.

Rappoport, P. and Reichlin, L., 1989. Segmented trends and non-stationary time series. The Economic Journal, 99(395), pp.168-177.

Taylor, J, B., 1982, Macroeconomic tradeoffs in an international economy with rational expectations, in: Hildebrand, ed., Advances in economic theory (Cambridge University Press, Cambridge).

Macroeconomic Policy in a World Economy: From Econometric Design to Practical Operation, W.W. Norton, New York, 1993. 
"Discretion Versus Policy Rules in Practice," Carnegie-Rochester Series on Public Policy, NorthHolland, 39, 1993, pp. 195-214.

Wicksell, Knut. "Interest and Prices, trans." RF Kahn with an introduction by (1898).

Woodford, M , Interest and Prices: Foundations of a Theory of Monetary Policy, Princeton: Princeton University Press, 2003.

Globalization and Monetary Control, in Galí, Jordi, and Mark Gertler, eds. International Dimensions of Monetary Policy. University of Chicago Press, 2010.

Yellen, Janet L. The Economic Outlook and the Conduct of Monetary Policy: a speech at the Stanford Institute for Economic Policy Research, Stanford University, Stanford, California, January 19, 2017. No. 935. 2017. 